\title{
The Interpretation of Isaiah 56:1-9: Comfort or Criticism?
}

\author{
RAYMOND DE HOOP \\ raymond.de.hoop@gmail.com \\ University of Pretoria, Pretoria 0002, South Africa
}

Isaiah 56:1-8 is described as a promise of salvation, ${ }^{1}$ an exhortation containing a prophetic Torah, ${ }^{2}$ or a prophetic oracle that introduces a new cultic norm. ${ }^{3}$ Its

This article is the "side effect" of a paper read at the seminar entitled "Pericope: Scripture as Written and Read in Antiquity" at the International Meeting of the Society of Biblical Literature in Edinburgh in 2006, which will be published separately (see n. 18). Thanks are due to Professors Ulrich Berges (Münster), Wim A. M. Beuken (Leuven), Paul Sanders (Utrecht), and Marvin A. Sweeney (Claremont), who were so kind to read a draft version of this paper and to offer me a number of valuable suggestions to improve my argument. Thanks are also due to Naomi Coward (Sentani, Indonesia), who was so kind to correct my English. No need to say that I alone am responsible for the views expressed in this paper.

Research for this paper was carried out as a research fellow of the University of Pretoria, South Africa. I wish to express my gratitude to the board of the Departement of Ancient Languages of the University of Pretoria for granting me this position. $43-44$.

${ }^{1}$ Jan L. Koole, Jesaja III vertaald en verklaard: Jesaja 56-66 (COuT; Kampen: Kok, 1995),

${ }^{2}$ Georg Fohrer, Einleitung in das Alte Testament (11th ed.; Heidelberg: Quelle \& Meyer, 1969), 422; Theodor Lescow, "Die driestufige Tora: Beobachtungen zu einer Form," $Z A W 82$ (1970): 362-79, esp. 370; R. Norman Whybray, Isaiah 40-66 (NCBC; Grand Rapids: Eerdmans; London: Marshall, Morgan \& Scott, 1975), 197; Claus Westermann, Das Buch Jesaja: Kapitel 4066 übersetzt und erklärt (ATD 19; 4th ed.; Göttingen: Vandenhoeck \& Ruprecht, 1981), 249; Herbert Donner, "Jesaja LVI 1-7: Ein Abrogationsfall innerhalb des Kanons-Implikationen und Konsequenzen," in Congress Volume: Salamanca 1983 (ed. John A. Emerton; VTSup 36; Leiden: Brill, 1985), 81-95, esp. 81; Wim A. M. Beuken, Jesaja deel IIIA (De prediking van het Oude Testament; Nijkerk: Callenbach, 1989), 20; Christoph Bultmann, Der Fremde im antiken Juda: Eine Untersuchung zum sozialen Typenbegriff 'ger' und seinem Bedeutungswandel in der alttestamentlichen Gesetzgebung (FRLANT 153; Göttingen: Vandenhoeck \& Ruprecht, 1992), 207-12.

${ }^{3}$ See Claus Westermann, Prophetische Heilsworte im Alten Testament (FRLANT 145; 
origin is to be found in the cultic context of the temple, in which the admission of foreigners and eunuchs was discussed in view of the regulations from the Torah, esp. Deut 23:3-9. ${ }^{4}$ On the other hand, the following passage, Isa 56:9-57:13, is classified as a "prophetic announcement of impending judgment," a "prophetic liturgy with threats," or "a chain of accusations." "These two interpretations have led to the almost universally accepted view that Isa 56:1-8 and 56:9-57:13 are not (or hardly) related to each other and that their present juxtaposition is attributable only to a redactor/writer. ${ }^{6}$

More recent studies have demonstrated, however, that both Isa 56:1-8 and 56:9-57:13 are closely related to Deutero-Isaiah and especially to ch. 55. ${ }^{7}$ The theme of the "Servant of Yнwh," for example, which has such a crucial position in Deutero-Isaiah, is continued in Trito-Isaiah as the "servants of YнwH" (56:6; 63:17; $65: 8-9,13-15 ; 66: 14) .{ }^{8}$ Similarly, the concept of the "mountain of YHWH" is elaborated in Trito-Isaiah $(56: 7 ; 57: 13 ; 65: 11,25 ; 66: 20)$, but in this case the theme is adapted from Proto-Isaiah ch. 11 ; it does not occur in Deutero-Isaiah. ${ }^{9}$ However,

Göttingen: Vandenhoeck \& Ruprecht, 1987), 185-86; Leszek Ruszbowski, “Der Sabbat bei Tritojesaja," in Prophetie und Psalmen: Festschrift für Klaus Seybold zum 65. Geburtstag (ed. Beat Huwyler et al.; AOAT 280; Münster: Ugarit, 2001), 61-74; Bernard Gosse, "Sabbath, Identity and Universalism Go Together after the Return from Exile," JSOT 29 (2005): 359-70, esp. 368-70. In this vein also, see Martinus A. Beek, "De vreemdeling krijgt toegang (Jesaja 56:1-8)," in De Knecht: Studies rondom Deutero-Jesaja aangeboden aan prof.dr. J. L. Koole (ed. Herman H. Grosheide et al.; Kampen: Kok, 1978), 17-22.

${ }^{4}$ See Westermann, Jesaja 40-66, 249, 252.

${ }^{5}$ See ibid., 253 (regarding 56:9-12); Fohrer, Einleitung, 423; Beuken, Isaiah IIIA, 45-46; Koole, Jesaja III, 65.

${ }^{6}$ Odil Hannes Steck, “Beobachtungen zu Jesaja 56-59,” BZ 31 (1987): 228-46, esp. 229-30; repr. in Studien zu Tritojesaja (BZAW 203; Berlin: de Gruyter, 1991), 169-86, esp. 170-71.

${ }^{7}$ See, e.g., Ulrich Berges, Das Buch Jesaja: Komposition und Endgestalt (HBS 16; Freiburg im Breisgau: Herder, 1998), 509-15. The relationship was noticed already in earlier studies, but was generally ignored with regard to the unity of the book. See, e.g., Fohrer, Einleitung, 421, who writes: "Trotz der Abhängigkeit einiger Abschnitte von Dtjes liegt ein tiefer Graben zwischen beiden Schriften."

${ }^{8}$ Wim A. M. Beuken, “The Main Theme of Trito-Isaiah: 'The Servants of YHWH,'” JSOT 47 (1990): 67-87; see also idem, "Trito-Jesaja: profetie en schriftgeleerdheid," in Profeten en profetische geschriften (ed. Florentino García Martínez et al.; Nijkerk: Callenbach, [1987]), 71-85, 78-83. Furthermore, see Gerhard Wallis, "Gott und seine Gemeinde," TZ 27 (1971): 182-200; Joseph Blenkinsopp, "The 'Servants of the Lord' in Third Isaiah: Profile of a Pietistic Group in the Persian Epoch," PIBA 7 (1983): 1-23; idem, "The Servant and the Servants in Isaiah and the Formation of the Book," in Writing and Reading the Scroll of Isaiah: Studies of an Interpretative Tradition (ed. Craig C. Broyles and Craig A. Evans; VTSup 70; Formation and Interpretation of Old Testament Literature 1: Leiden: Brill, 1997), 155-75.

${ }^{9}$ Wim A. M. Beuken, "Isa. 56:9-57:13-An Example of the Isaianic Legacy of Trito-Isaiah," in Tradition and Reinterpretation in Jewish and Early Christian Literature: Essays in Honour of

\footnotetext{
This article was published in JBL 127/4 (2008) 671-95, copyright @ 2008 by the Society of Biblical Literature. To purchase copies of this issue or to subscribe to JBL, please contact SBL Customer Service by phone at 866-727-9955 [toll-free in
} North America] or 404-727-9498, by fax at 404-727-2419, or visit the online SBL Store at www.sbl-site.org. 
because of the strong emphasis on the proclamation of "salvation," which seems to be in contrast to the following unit (Isa 56:9-57:13), Isa 56:1-8 is still considered to be more or less independent from the next pericope. ${ }^{10}$

This supposition of a gap between the two pericopes is strengthened by the contents of the first verse of the second pericope, Isa 56:9. ${ }^{11}$ The verse is considered to be a negative saying, forming the introduction to the following oracle on the leaders of Israel as a kind of sarcastic prelude. Yet the delimitation of sense units in the textual tradition of the book of Isaiah suggests a different interpretation of this verse. If in the ancient manuscripts a pause was read at the end of Trito-Isaiah's first pericope, it is read after v. 9 instead of before, thus reading v. 9 together with the preceding verses and not with the following verses. ${ }^{12}$ What do such readings suggest regarding the interpretation of the text and what is the implication of it for our exegesis? If the position of the break between the first pericope and the second in TritoIsaiah moves back, this may have consequences for its interpretation. Is the supposed gap between the first and the second pericope so deep indeed, as is usually assumed? Or is there much more continuity between the two passages that was formerly overlooked? And if there is indeed some continuity between the two passages, is Isa 56:1-8(9) in that case a promise of salvation, or is it a polemical and critical text in line with the following passage? These questions will be the main topic of this article. First, I will briefly discuss the delimitation of the pericope in the light of the ancient witnesses. Subsequently I will explore the main message of this first pericope in Trito-Isaiah, which then will be studied from the perspective of its literary context. This will be followed by a discussion of some moments of the Wirkungsgeschichte of the text, reflecting already some aspects of my proposed interpretation of the text. Finally I will formulate some conclusions.

\section{IsAiAh 56:9: INTRODUCTION OR CONCLUSION?}

Isaiah 56:8-9 reads as follows:

$\begin{array}{rr}8 a \\ \text { נאם אדני יהוה נדחי ישראל } & \text { 8b }\end{array}$

J. C. H. Lebram (ed. Jan Willem van Henten et al.; SPB 36; Leiden: Brill, 1986), 48-64, esp. 50; Marvin A. Sweeney, "Prophetic Exegesis in Isaiah 65-66," in Writing and Reading the Scroll of Isaiah, ed. Broyles and Evans, 455-74; idem, "The Reconceptualization of the Davidic Covenant in Isaiah," in Studies in the Book of Isaiah: Festschrift Willem A. M. Beuken (ed. Jacques van Ruiten and Marc Vervenne; BETL 132; Leuven: Peeters, 1997), 41-62, esp. 51-52.

${ }^{10}$ Beuken, "Isa. 56:9-57:13," 50; Blenkinsopp, “Servant and the Servants," 166.

${ }^{11}$ According to Beuken (Jesaja IIIA, 48), "the exhortation to the wild animals to come to eat surprises and has nothing in common with the preceding text" ("[d]e oproep tot de wilde dieren om te komen eten verrast en heeft geen enkel aanknopingspunt met het voorafgaande").

${ }^{12}$ See for the moment only BHS; and in addition n. 18 below.

This article was published in JBL 127/4 (2008) 671-95, copyright (־ 2008 by the Society of Biblical Literature. To purchase copies of this issue or to subscribe to JBL, please contact SBL Customer Service by phone at 866-727-9955 [toll-free in North America] or 404-727-9498, by fax at 404-727-2419, or visit the online SBL Store at www.sbl-site.org. 


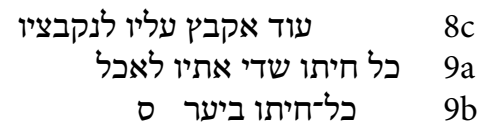

Word of the Lord Yнwh, gathering the outcast of Israel:

"I will gather to him still more ${ }^{13}$ beyond those already gathered.

All beasts of the field come to eat, all beasts of the forest."

In every recent translation of the Hebrew Bible the first pericope of TritoIsaiah is considered to be 56:1-8. ${ }^{14}$ The following verse, Isa 56:9, is considered to be like an anacrusis to 56:10-13, introducing the animals coming to devour in the land, where the watchers neglect their task. The verb אכל is in that case rendered by "to devour" instead of the more common "to eat, to feed (both man and animal)." 15 This interpretation of אכל as "to devour" has been questioned by Wim A. M. Beuken, because no object to be devoured is mentioned in the text, neither in v. 9 nor in the following verses. ${ }^{16}$

Since Isa $56: 9$ seems to be an adaptation of Jer $12: 9,{ }^{17}$ it is usually read as a sort of judgment on (the leaders of) Israel. The ancients, however, apparently preferred to read v. 9 together with the previous v. 8 , in which the promise "I will gather

${ }^{13}$ Hebrew עוד is taken here in the sense of "still more, in addition to"; see NJPSV; cf. HALAT, 752; Beuken, Jesaja IIIA, 35; Koole, Jesaja III, 62.

${ }^{14}$ NJPSV; NAB; NEB; NIV; RSV; NRSV; EÜ (Einheits Übersetzung); LB; KBS (Katholieke Bijbelstichting); NBG (Nederlands Bijbel Genootschap); NBV (De Nieuwe Bijbelvertaling); Martin Buber, Bücher der Kündung (Heidelberg: L. Schneider, 1958), 177-78; La Bible: Ancien et Nouveau Testament (Villiers-le-Bel: Alliance Biblique Français, 1997) (although starting with a new pericope before v. 9, the text also starts a new indentation after it).

${ }^{15}$ BDB, 37; HALAT, 44; Wilhelm Gesenius, Hebräisches und Aramäisches Handwörterbuch über das Alte Testament (18th ed.; ed. Rudolf Meyer and Herbert Donner; 4 vols.; Berlin/New York: Springer, 1987-2007), 53; DCH 1:240-42.

${ }^{16}$ The Masoretes accentuated the verse in such a way that the beasts of the forest are to be eaten by the beasts of the field. See David B. Freedman and Miles B. Cohen, "The Masoretes as Exegetes: Selected Examples," in 1972 and 1973 Proceedings of the International Organization for Masoretic Studies (ed. Harry M. Orlinsky; SBLMasS 1; Missoula, MT: Society of Biblical Literature, 1974), 35-46; in addition see Beuken, "Isaianic Legacy," 48-64; idem, Jesaja IIIA, 48; Koole, Jesaja III, 66. See also Targum Pseudo-Jonathan, which added the object from a comparable text, Ezek 39:14; see Raymond de Hoop, "Isaiah 56:1-9 in Targum Jonathan: A Comment" (forthcoming).

${ }^{17}$ See Whybray, Isaiah 40-66, 200 (using such terms as "resemble, ... hardly . . slavish imitation"); John D. W. Watts, Isaiah 34-66 (WBC 25; Waco: Word Books, 1987), 255-60; Koole, Jesaja III, 66-67; Berges, Das Buch Jesaja, 466 with n. 257. Cf., however, the cautious remarks in Beuken, "Isaianic Legacy," 56-58; idem, Jesaja IIIA, 48-50.

This article was published in JBL 127/4 (2008) 671-95, copyright ( 2008 by the Society of Biblical Literature. To purchase copies of this issue or to subscribe to JBL, please contact SBL Customer Service by phone at 866-727-9955 [toll-free in North America] or 404-727-9498, by fax at 404-727-2419, or visit the online SBL Store at www.sbl-site.org. 
to him still more beyond those already gathered" is given. The Leningrad Codex reads a $z i a h$ (indicated by 0 in BHS) after v. 9 and not, as $B H S$ seems to prefer, after v. $8{ }^{18}$ The Leningrad division is supported by other major witnesses: a petuha in Codex Cairo and Codex Aleppo, and a setuma in Codex Babylonicus Petropolitanus, Codex Reuchlinianus, Parma Bible, Rabbinic Bible, as are most of the other delimiters in this chapter (before 56:1, 3, 4, 6) ${ }^{19}$ In addition, the ancient manuscripts from Qumran (1QIs and $1 \mathrm{QIs}{ }^{\mathrm{b}}$ ) support this delimitation of v. 9, while they also in general support the delimitation of ch. 56 by means of petuhot and setumot. ${ }^{20}$ Further, a number of important manuscripts of Targum Jonathan have a break after 56:9. ${ }^{21}$ (The LXX, the Peshitta, and most manuscripts of the Vulgate do not read a break before or after v. 9.22) Does this delimitation of the text suggest a more positive interpretation of v. 9, implying that the invitation to the beasts of the field and the forest has a positive tenor in line with the preceding verses? ${ }^{23}$ The fact

\footnotetext{
${ }^{18}$ See Raymond de Hoop, "Delimitation Criticism and Exegesis: Isaiah 56 as an Introduction to the Theme," in The Impact of Delimitation Criticism on Exegesis (ed. Raymond de Hoop et al.; Pericope 7; Leiden: Brill, 2008), 1-28, esp. 4, and plate 2. A ziah is indicated as a setuma in BHS, but is in fact an indentation to the left of a new line, often preceded by a petuha; see Marjo C. A. Korpel, "Introduction to the Series Pericope," in Delimitation Criticism (ed. Marjo C. A. Korpel and Josef M. Oesch; Pericope 1; Assen: Van Gorcum, 2000), 1-50, here 3-4.

${ }^{19}$ See Josef M. Oesch, Petucha und Setuma: Untersuchungen zu einer überlieferten Gliederung im hebräischen Text des Alten Testaments (OBO 27; Freiburg: Universitätsverlag; Göttingen: Vandenhoeck \& Ruprecht, 1979), 221-22, T26+; see also Koole, Jesaja III, 64-65.

${ }^{20}$ Scholars differ in their interpretations of the spaces in 1QIs ${ }^{\mathrm{b}}$. Eugene Ulrich ("Impressions and Intuition: Sense Divisions in Ancient Manuscripts of Isaiah," in Unit Delimitation in Biblical Hebrew and Northwest Semitic Literature [ed. Marjo C. A. Korpel and Josef M. Oesch; Pericope 4; Assen: Van Gorcum, 2003], 279-307) does not discern a space after Isa 56:9/before 56:10 (see esp. 295), while, for example, Oesch does (Petucha und Setuma, 221-22, T26+). In addition, see now de Hoop, "Delimitation Criticism," 6 n. 13, and plate 4, with an image of Isaiah 56 in 1 QIs , where the space, indicating a setuma after v. 9, is shown.

${ }^{21}$ Namely, Ms Solger 2-4 (Nuremberg); Ms Or. 2211 ([Margoliouth/London 138] London), Ms hébreu 1325 (Paris), and ms hébreu 75 (Paris); de Hoop, "Delimitation Criticism," 9 n. 18.

${ }^{22}$ There is only one manuscript of the Vulgate that starts a new pericope before Isa 56:9; most of the others start a new pericope at Isa 57:1, reading the first chapter of Trito-Isaiah thus as one pericope; see Biblia Sacra iuxta Latinam Vulgatam Versionem ad codicum fidem iussu Pauli PP. VI, Tom. 13: Libri Isaie (Rome: Typis Polyglottis Vaticanis, 1969).

Regarding these traditions, see de Hoop, "Delimitation Criticism." On the other hand, LXX, for example, has a break before $56: 1,3,6 \mathrm{~b} \beta$ and $57: 2 \mathrm{~b}$, but no break before or after $56: 9$. Syr ${ }^{\mathrm{b}}$ reads a break before 55:6 (cf. setuma in the MT), while $\mathrm{Syr}^{\mathrm{c}}$ has a break only before 55:1 and then finally after 57:14 (see de Hoop, "Delimitation Criticism," 8-9).

${ }^{23}$ See Oesch, who considers the possibility that $56: 9$ was related allegorically to $56: 6-8$ (Petucha and Setuma, 221-22). This suggestion is taken up by Berges, who asks whether this delimitation and interpretation suggest a negative attitude toward the joining of foreigners to the community, who are similar to "wild beasts" who will graze Israel bare (Das Buch Jesaja, 465
}

This article was published in JBL 127/4 (2008) 671-95, copyright @ 2008 by the Society of Biblical Literature. To purchase copies of this issue or to subscribe to JBL, please contact SBL Customer Service by phone at 866-727-9955 [toll-free in North America] or 404-727-9498, by fax at 404-727-2419, or visit the online SBL Store at www.sbl-site.org. 
that the oracles of doom in Jeremiah 12 are not found in Isaiah 56 diminishes the necessity of a negative interpretation considerably. In addition, there is another text that, like Jer 12:9, is a parallel to our text (Isa 56:9) and might shed a different light on the question of a negative or positive interpretation: Ezek 39:17, "Speak to the birds of every kind and to all the wild animals (חית השדה): Assemble (קבץ) and come (בוא), ${ }^{24}$ gather from all around to the sacrificial feast that I am preparing for you, a great sacrificial feast on the mountains of Israel, and you shall eat (אכל) flesh and drink blood." Remarkable is the fact this text employs the verb קבץ, which is used also in Isa 56:8, but there with a clearly positive tenor. This suggests that one cannot deduce from the mere fact that a more or less parallel text such as Jer 12:9 or Ezek 39:17 has a negative tenor that Isa 56:9 should also be interpreted in a similarly negative vein; the interpretation has to be determined by its context. In case of Isa 56:9 the context is somewhat ambiguous: vv. 1-8 seem to have a positive purport, while vv. 10-12 have a clear critical tenor.

In Hos 2:20 (Eng. 2:18), we read of the possibility that Yнwн will make a covenant with the beasts of the field, which might suggest that in our text (56:9) YHwh invites animals as part of the new era to come. Such a covenant is frequently called ברית עולם, "everlasting covenant" (Gen 9:16; Ezek 37:26) or ברית שלום, "covenant of peace" (Isa 54:10; Ezek 34:25), reflecting the stability of creation. In this connection it is relevant to refer to the close relationship between Isa 56:7, 8 and Isa 11:1-12, 16; the former employs language and imagery from the latter. ${ }^{25}$ The themes "mountain of YHWH" and the "gathering of the dispersed" are applied in both texts (Isa 11:9, 12, 16; 56:7, 8) ${ }^{26}$ It seems worthwhile, therefore, to consider the possibility

n. 251). Yet this attitude toward proselytes is not reflected in the targumic rendering of the text and hardly at all in rabbinic literature; see Beek, "De vreemdeling," 18-19; Str-B 1:355-56.

${ }^{24}$ The verb בוא in Ezek 39:17 can be considered to be a parallel to the verb אתה in Isa 56:9; see DCH 2:118; and cf. Deut 33:2; Mic 4:8; Job 3:25; and Prov 1:27.

${ }^{25}$ Beuken, "Isaianic Legacy," 50-52; Wolfgang Lau, Schriftgelehrte Prophetie in Jes 56-66 (BZAW 225; Berlin: de Gruyter, 1994), 262-79; Sweeney, "Reconceptualization," 51-52; see also Odil Hannes Steck, “Zu jüngsten Untersuchungen von Jes 56,1-8; 63,7-66,24," in idem, Studien $z u$ Tritojesaja, 229-68, here 248 n. 119.

${ }^{26}$ Sweeney ("Prophetic Exegesis," 467-68) refers to the fact that the "tree" and "seed" imagery of Isaiah 6 is also employed in chs. 65-66, and there is also a strong connection with Isaiah 11, esp. v. 1: "a new shoot shall go forth from the stump of Jesse and a shoot shall sprout from its roots." Moreover, this imagery of the "stump" in Isaiah 11 seems to recur in ch. 56, when the ("eunuch") complains הן אני עץ יבש, "behold I am just a dry tree" (56:3). This is not a matter of coincidence, but fits with the general tendency of Trito-Isaiah to reformulate and apply imagery from Proto-Isaiah and Deutero-Isaiah. The imagery of the "stump" is applied to the members of this community, reformulating the Davidic covenant with regard to the community of "servants of Yнwн," which has been argued already by Sweeney ("Reconceptualization"); and Ulrich Berges, "Die Knechte im Psalter: Ein Beitrag zu seiner Kompositionsgeschichte," Bib 81 (2000): 153-78; idem, "Who Were the Servants? A Comparative Inquiry in the Book of Isaiah and the Psalms," in

\footnotetext{
This article was published in JBL 127/4 (2008) 671-95, copyright @ 2008 by the Society of Biblical Literature. To purchase copies of this issue or to subscribe to JBL, please contact SBL Customer Service by phone at 866-727-9955 [toll-free in
} North America] or 404-727-9498, by fax at 404-727-2419, or visit the online SBL Store at www.sbl-site.org. 
of reading Isa 56:9 from a similar perspective, that is, using the imagery of Isa 11:68 , where the peaceful presence of serpent (65:25; cf. 11:8), wolf (11:6; 65:25), bear (11:7), leopard (11:6), and lion (11:7) is foreseen. ${ }^{27}$ From this perspective, the invitation of the beasts in 56:9 is a summary of Isa 11:6-8 in which a kind of eschatological perspective is offered. The beasts' presence at the mountain is not threatening: "They will not hurt or destroy on all my holy mountain" (11:9). DeuteroIsaiah suggested already that even חית השדה, "the beasts of the field," will come to praise YHWH (43:20). In this way, Isa 56:9 might be understood as an invitation to the beasts of the field and the forest to participate in the salvation at the mountain of the Lord. This is in accordance with the preceding verses, which, as was noted above, adapt the themes from Isaiah 11 . In this connection, it is interesting to refer to Exod 31:16, where observing the Sabbath is mentioned as a ברית עולם. ${ }^{28}$ Whether the tenor is generally optimistic and friendly, however, might be a matter of dispute, to which we will return at the end of the following section.

It should be questioned, however, whether the general delimitation of the first two pericopes of Trito-Isaiah (viz., 56:1-8 and 56:9-57:13) is entirely wrong, if we were to follow the delimitation found in the ancient extant manuscripts. It is obvious that the imagery of the חית השדה/יער, "beasts of the field/forest," also is to be related to the following verses, where we find the imagery of the כלבים, "dogs" (56:10, 11) and the רעים, "shepherds" (56:11). ${ }^{29}$ But this intertwining of images begins already in 56:8, where Yнwн depicts himself as a shepherd, who gathers

Past, Present, Future: The Deuteronomistic History and the Prophets (ed. Johannes C. de Moor and Harry F. van Rooy; OTS 44; Leiden: Brill, 2000), 1-18.

${ }^{27}$ The serpent and the wolf are to be considered "beasts of the field" (see Gerhard Wallis,

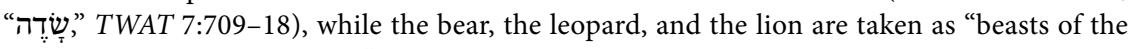
wood" (see Martin J. Mulder, "יעַרי," TWAT 3:777-87). Whether the leopard should be seen as a "beast of the field" or of "the forest" depends on its line of descent; see Adriaan Schouten van der Velden, Dieren uit de Bijbel: Een inventarisatie en beschrijving (Nijkerk: Callenbach, 1992), $110-11$.

${ }^{28}$ Roy D. Wells (“'Isaiah' as an Exponent of Torah: Isaiah 56.1-8," in New Visions of Isaiah [ed. Roy F. Melugin and Marvin A. Sweeney; JSOTSup 214; Sheffield: Sheffield Academic Press, 1996; repr., Atlanta: Society of Biblical Literature, 2006], 140-55, esp. 144) refers in this connection to the fact that Sabbath observance is a metonym for the recurring phrase "hold fast my covenant" (Isa 56:4, 6), whereas observance of the Sabbath received in Exod 31:12-17 a cosmological status, as it "features Creation as the rationale for the Sabbath" (Nahum M. Sarna, Exodus = שמות: The Traditional Hebrew Text with the New JPS Translation [JPS Torah Commentary; Philadelphia: Jewish Publication Society, 5751/1991], 201). See also in this connection Isa 66:2-3, where the eschatological perspective of the Sabbath plays an important part in the new creation; see Gosse, "Sabbath, Identity and Universalism," 369.

${ }^{29}$ See, e.g., Beuken, Jesaja IIIA, 48; Koole, Jesaja III, 66-67; Berges, Das Buch Jesaja, 46566.

This article was published in JBL 127/4 (2008) 671-95, copyright $\odot 2008$ by the Society of Biblical Literature. To purchase copies of this issue or to subscribe to JBL, please contact SBL Customer Service by phone at 866-727-9955 [toll-free in North America] or 404-727-9498, by fax at 404-727-2419, or visit the online SBL Store at www.sbl-site.org. 
(קבץ) the dispersed and will gather even more (cf. Isa 40:11), ${ }^{30}$ an image that is best illustrated by the situation as described in Nah $3: 18:^{31}$

Your shepherds (רעיך) are asleep (נמו), O king of Assyria, your nobles slumber

Your people are scattered (נפשו) on the mountains with no one to gather (מקבץ) them.

The function of good רעים ("shepherds") is to gather the dispersed, but now YнwH will do it himself, because the shepherds "have turned their own way" (56:11; cf. 53:6). ${ }^{32}$ So it appears that Isa 56:8-9, on the one hand, forms the closure of the preceding verses but, on the other hand, opens the rebuke of the leaders in the following verses. In that sense the proclamation found in Isa 56:8-9 seems to have the function of a Janus-text, looking backward and forward. ${ }^{33}$ It seems, therefore, that the delimitation of the text found in the MT, 1QIsa ${ }^{a}$, and 1QIsa ${ }^{b}$-keeping Isa 56:8-9 together and not separating the verses over two pericopes-offers a quite viable reading. In addition, the delimitations found in the Greek version of Symmachus, the Syriac, and the Vulgate, which do not seem to read a break before or after these verses, ${ }^{34}$ do justice to the interpretation of 56:8-9 as a passage with a Janus-function.

\section{The Central Theme of Isaiah 56:1-9}

The central theme of Trito-Isaiah is the question "Who are the servants of Yнwн?"35 This question is answered, for example, in 56:6-7a $\alpha$ :

\footnotetext{
And the foreigners (ובני הנכר) who join themselves to the LoRD, to minister to him (לשרתו), to love the name of the LoRD, and to be his servants (לעבדים)

all who keep the sabbath, and do not profane it,
}

${ }^{30}$ Beuken, "Isaianic Legacy," 60; idem, Jesaja IIIA, 50.

${ }^{31}$ See also Jer 31:10; Ezek 34:13. On the text-critical questions and translation of Nah 3:18, see Klaas Spronk, Nahum (Historical Commentary on the Old Testament; Kampen: Kok Pharos, 1997), 141-43.

${ }^{32}$ Beuken, "Isaianic Legacy," 60; idem, Jesaja IIIA, 51.

${ }^{33}$ The terminology is mostly applied to poetry, where it is referred to as "Janus parallelism"; see Wilfred G. E. Watson, Classical Hebrew Poetry: A Guide to Its Techniques (JSOTSup 26; 2nd ed.; Sheffield: JSOT Press, 1986), 156-59.

${ }^{34}$ See n. 22 above.

${ }^{35}$ Beuken, "Main Theme," 67-87; idem, "Trito-Jesaja: profetie en schriftgeleerdheid," 7185. See also Wallis, "Gott," 182-200; Blenkinsopp, "Servants of the Lord," 1-23; idem, "Servant and the Servants," 155-75; Ulrich Berges, "Die Armen im Buch Jesaja: Ein Beitrag zur Literaturgeschichte des AT," Bib 80 (1999): 153-77, esp. 166-75; idem, “Who Were the Servants?" 1-18.

\footnotetext{
This article was published in JBL 127/4 (2008) 671-95, copyright @ 2008 by the Society of Biblical Literature. To purchase copies of this issue or to subscribe to JBL, please contact SBL Customer Service by phone at 866-727-9955 [toll-free in
} North America] or 404-727-9498, by fax at 404-727-2419, or visit the online SBL Store at www.sbl-site.org. 
and hold fast my covenant,

these I will bring to my holy mountain.

The answer to this question suggests a polemic with certain groups in Israel's community. ${ }^{36}$ At an intertextual level, this polemic seems to focus on texts like Deut 23:2 and its possible "derivatives" in narrative and prophetic literature such as Ezra 9; Nehemiah 9; and Ezekiel 44. ${ }^{37}$ When reading Isa 56:1-9, however, once again it might appear that this is only partly true, that the text might have a slightly different purport, not solely a polemical but especially a critical import.

The message of the prophet is quite obvious with regard to YHwH's attitude toward the foreigner and the eunuch, despite certain laws and despite the oracles of other prophets-the Israelite community should be an open community. As Sweeney rightly states, however, "these chapters do not provide an overall warrant for the blanket inclusion of the nations in YHwH's covenant." ${ }^{38}$ In both cases (of the eunuch and the foreigner) it is obvious that those "who keep (שמר) the sabbath (far from profaning it)" and "hold fast (חזק) the covenant" are welcome on God's mountain. These conditions have to be read in the light of the opening verses of our passage, Isa $56: 1-2:^{39}$

Thus says Yнwн:

Maintain (שמרו) justice (משפט), and do (ועשו) righteousness (צדקה),

for soon my salvation (ישועתי) will come,

${ }^{36}$ Westermann, Jesaja 40-66, 249, 252; Wallis, “Gott," 186-89; Sara Japhet, “יד ושם (Isa 56:5) -A Different Proposal," Maarav 8 (1992): 69-80, esp. 79-80; Michael Fishbane, "The Hebrew Bible and Exegetical Tradition," in Intertextuality in Ugarit and Israel (ed. Johannes C. de Moor; OTS 40; Leiden: Brill, 1998), 15-30, esp. 26-28.

${ }^{37}$ See Wallis, "Gott," 188-89; Steck, "Jüngsten Untersuchungen," 248; Westermann, Jesaja 40-66, 249-50; Donner, “Jesaja LVI 1-7," 82-84; Fishbane, "Exegetical Tradition," 26-28. The idea that this text especially aims at situations that occurred during the era of Ezra and Nehemiah was criticized by Steck, "Jüngsten Untersuchungen," 246-47 n. 111; Christopher R. Seitz, "Isaiah, Book of (Third Isaiah)," ABD 3:501-7, esp. 502-4; Marvin A. Sweeney, "The Book of Isaiah as Prophetic Torah," in New Visions of Isaiah, ed. Melugin and Sweeney, 57-58; but compare Berges, Das Buch Jesaja, 509-15. In addition to Ezekiel 44, Wallis also refers to Hag 2:10-19, which might be reflected in this passage (Wallis, "Gott," 188-89). In that sense, the passage is considered to represent a more liberal approach to a rigid and normative religion; see Whybray, Isaiah 40-66, 197; Franz J. Stendenbach, "Überlegungen zum Ethos des Alten Testaments," Kairos 18 (1976): 273-81.

${ }^{38}$ Sweeney, "Reconceptualization," 51 . This was stressed already by Harry M. Orlinsky ("The So-Called 'Servant of the Lord' and 'Suffering Servant' in Second Isaiah," in Harry M. Orlinsky and Norman H. Snaith, Studies on the Second Part of the Book of Isaiah [VTSup 14; 2nd ed.; Leiden: Brill, 1977], 1-133, esp. 37-38), who stated that this passage gives strict rules for those who are allowed to enter the mountain of Yнwн. See also Beuken, "Isaianic Legacy," 51-52, who emphasizes that the conditions on which one can enter the holy mountain are one of the themes TritoIsaiah elucidates. See also Beek, "De vreemdeling," 18, 22; Wells, "Exponent of Torah," 140-55.

${ }^{39}$ See also the observations on this text in Berges, Das Buch Jesaja, 509-10.

This article was published in JBL 127/4 (2008) 671-95, copyright (־ 2008 by the Society of Biblical Literature. To purchase copies of this issue or to subscribe to JBL, please contact SBL Customer Service by phone at 866-727-9955 [toll-free in North America] or 404-727-9498, by fax at 404-727-2419, or visit the online SBL Store at www.sbl-site.org. 
and my righteousness (וצדקתי) be revealed.

Happy is the mortal who does this, the one who holds (יחזיק) it fast,

who keeps (שמר) the sabbath, not profaning it, and refrains from doing (עשה) any evil.

The context of the passage suggests the need for the exhortation to maintain justice and to do righteousness. But instead of a harsh condemnation, the criticism is formulated in a positive tone: "happy is the mortal . ..." This positive formulation (together with a part of the Wirkungsgeschichte of the text [esp. 56:4-5] in the $\mathrm{NT}^{40}$ ) has led scholars to emphasize the element of salvation only. J. L. Koole, for example, states that God's coming salvation and righteousness are not threatening "like an axe laid to the root of the trees (Mat. 3:10)."41 Similarly John N. Oswalt wrote:

there is a whole new motivation for doing righteousness. It is not now so much the fear of impending doom which compels righteousness, as it is the recognition that God is going to mercifully and righteously keep his covenant promises. We should be righteous, the writer says, because of the righteousness of God. This point is followed throughout the section: Human obedience should be the natural result of divine faithfulness. ${ }^{42}$

When the passage is read in this vein, it has a completely different tenor from that of the following criticisms of Isa 56:10-59:21. ${ }^{43}$ In Isa 56:1-8/9, however, there is no reference to God's mercy, to keeping the covenant promises. But even so, it should be asked what God's salvation and righteousness imply: Do these also imply that the oppressors of the poor, the foreigner, the widow, and the orphan will receive righteousness and mercy after their deeds? Those who do not keep their

${ }^{40}$ The narrative about the conversion of the Ethiopian eunuch in Acts 8:26-40 undoubtedly contributed to the "universalistic" interpretation of this passage, in which the "ethical" aspect of the text was generally ignored in favor of a universalistic aspect. See Johannes Schneider,

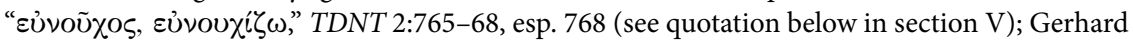
Schneider, Apostelgeschichte, erster Teil, Einleitung, Kommentar zu Kap. 1,1-8,40 (HTKNT; Freiburg: Herder, 1980), 498-500. Contrast, however, Rudolf Pesch, Die Apostelgeschichte, 1. Teilband, Apg 1-12 (EKK 5/1; Zurich: Benziger; Neukirchen-Vluyn: Neukirchener Verlag, 1986), 289, with $\mathrm{n}$. 22, who doubts the relationship between these texts, arguing that Isa 56:3-5 emphasizes legal matters, and especially the Sabbath.

${ }^{41}$ Koole, Jesaja III, 41.

${ }^{42}$ John N. Oswalt, "Righteousness in Isaiah: A Study of the Function of Chapters 56-66 in the Present Structure of the Book," in Writing and Reading the Scroll of Isaiah, ed. Broyles and Evans, 188 (emphasis added).

${ }^{43}$ In a similar vein, see E. J. Young, The Book of Isaiah, vol. 3, Chapters 40 through 66: The English Text, with Introduction, Exposition, and Notes (NICOT; Grand Rapids: Eerdmans, 1972), 388-89. 
hand from doing any evil, those who profane the Sabbath ${ }^{44}$ In the light of the following verses (vv. 3-7), this is clearly not correct: there are strict regulations for those who are to enter הר קדשי, "my holy mountain," and the exhortation to maintain justice and do righteousness emphasizes this aspect. Moreover, a positive interpretation of the text cannot be justified in view of the context, for instance, Isa 59:15-20, esp. vv. 17b-18, where one reads of "vengeance," "fury," "repaying," and "wrath." 45

On the other hand, the need for such an admonition suggests that justice and righteousness were lacking in the community-hence the origin of the present passage in the threat of God's righteousness. The criticism of certain groups is implicitly present in our passage because a quite obvious commandment of the Torah (Deut 23:2-9) is abrogated in order to emphasize the importance of other laws: ${ }^{46}$ keep the Sabbath (Isa 56:2, 4, 6), hold fast to justice/righteousness/the covenant (vv. 2, 4, 6), refrain from doing any evil/choose things that please God (v. 2, 4). It has been noticed by scholars that the stipulations in this text do not mention circumcision. ${ }^{47}$ This might be explained by the fact that the emphasis here is on being recognized as a member of God's people through continuous, right, ethical behavior, not through a single act. Moreover, one might ask whether circumcision was a matter of concern during this era. ${ }^{48}$ The answer to the complaints of the eunuch and

\footnotetext{
${ }^{44}$ The tendency to deny God's justice and righteousness as threatening and dangerous is criticized by Ulrich Berges, "The Violence of God in the Book of Lamentations," in One Text, A Thousand Methods: Studies in Memory of Sjef van Tilborg (ed. Patrick Chatelion Counet and Ulrich Berges; Biblical Interpretation Series 71; Leiden: Brill, 2005), 21-44. In addition, see Wim A. M. Beuken, "Obdurate Short-Sightedness in the Valley of Vision: How Atonement of Iniquity Is Forfeited (Isa 22:1-14)," in ibid., 45-63; Ulrich Berges, "Der Zorn Gottes in der Prophetie und Poesie Israels auf dem Hintergrund altorientalischer Vorstellungen,” Bib 85 (2004): 305-30.

${ }^{45}$ On this passage, see Berges, Das Buch Jesaja, 421. It is quite remarkable that Koole in his commentary on Isa 59:15-20 ignores the parallelism with Isa 56:1-8/9 (Jesaja III, 212). Although Oswalt ("Righteousness in Isaiah," 188) refers to Isa 59:14-18, which "dramatically underlined" the linkage of human obedience because of divine faithfulness, this reference ignores, in my opinion, the fact that Isa 59:15-20 announces impending doom for those who do not obey and who oppress those who turn from evil. It is not so much God's faithfulness that motivates one in this case as the threat of his coming wrath and justice, which is used here as a motivation.

${ }^{46}$ Beek, "De vreemdeling," 20; Westermann, Jesaja 40-66, 250; Donner, "Jesaja LVI 1-7," 81-95; Bultmann, Der Fremde, 211.

${ }^{47}$ E.g., Hans Klein, "Die Aufnahme Fremder in die Gemeinde des Alten und des Neuen Bundes," TBei 12 (1981): 21-34, here 29; Koole, Jesaja III, 52; Berges, Das Buch Jesaja, 419, 510, 513, 531; Gosse, "Sabbath, Identity and Universalism," 369 n. 15. Cf., however, Bultmann, Der Fremde, 200-201, who considers the term ברית ("covenant”) to refer to circumcision. Yet Beek ("De vreemdeling," 17-18) and Wells ("Exponent of Torah," 143-45) both refer to Exod 31:12-17, to which Isa 56:1-8 seems to allude or which even is echoed in it, stating that the Sabbath shall be an ("sign") (cf. Isa 55:13) between Yнwh and his people.

${ }^{48}$ Circumcision is not a specific Israelite rite; it was practiced also by Egyptians, Edomites,
}

This article was published in JBL 127/4 (2008) 671-95, copyright @ 2008 by the Society of Biblical Literature. To purchase copies of this issue or to subscribe to JBL, please contact SBL Customer Service by phone at 866-727-9955 [toll-free in North America] or 404-727-9498, by fax at 404-727-2419, or visit the online SBL Store at www.sbl-site.org. 
the foreigner in this text is an implicit criticism of leaders who apparently follow certain laws of the Torah but neglect more important ones. This becomes clear when we examine Isa 56:1-9 in its Trito-Isaianic context.

\section{Isaiah 56:1-9 in the Literary ConteXt of Trito-Isaiah}

Isaiah 56:1-8 is generally considered to have been put in its present context, preceding 56:9-59:13, by a later hand (editor/writer). This seems to imply that its message is only a later addition to the criticisms found in 56:9-59:21. Apparently the promise of God's salvation and righteousness to come, in combination with the promise to foreigners and eunuchs, has led to this literary-critical judgment on the pericope. $^{49}$

As stated above, recent studies demonstrate the dependence of our passage on other texts in the book of Isaiah, for example, ch. 11. In addition, it has been demonstrated that Isa $56: 1-8 / 9$ is closely connected to chs. 54 and $55,{ }^{50}$ similar to

Ammonites, Moabites, and Arabs, according to Jer 9:24-25 (but contrast [the late] Jdt 14:10); see Jack M. Sasson, "Circumcision in the Ancient Near East," JBL 85 (1966): 473-76. For that reason it might be a matter of dispute when this institution became the sign of the covenant between YHWH and the people and in that sense of axial importance: Was it already during the exile or during the Hellenistic era, from which we have some narratives of converted Gentiles being circumcised (Jdt 14:10; Esth. 8:17 LXX)? See Roland de Vaux, The Early History of Israel (London: Darton, Longman \& Todd, 1978), 286-87; idem, Ancient Israel: Its Life and Institutions (1965; repr., Biblical Resources Series; Grand Rapids: Eerdmans, 1997), 46-48; Werner H. Schmidt, Exodus, 1. Teilband, Exodus 1,1-6,30 (BKAT 2/1; Neukirchen-Vluyn: Neukirchener Verlag, 1978), 228; Robert G. Hall, "Circumcision,” $A B D$ 1:1025-31.

${ }^{49}$ This was especially argued by Odil Hannes Steck, "Tritojesaja im Jesajabuch," in The Book of Isaiah: Le livre d'Isaïe. Les oracles et leurs relectures (ed. Jacques Vermeylen; BETL 81; Leuven: Peeters, 1989), 361-406, esp. 390-91; repr. in idem, Studien zu Tritojesaja, 3-45, here 31 n. 81. Steck considers the possible relationship of 56:1 with the following (56:9-59:21) but rejects this relationship as being an organic one; he allows for a relationship only at the level of a later additional layer ("jüngere Erweiterungsschicht").

${ }^{50}$ Rolf Rendtorff, Das Alte Testament: Eine Einführung (Neukirchen-Vluyn: Neukirchener Verlag, 1983), 211-12; idem, “Zur Komposition des Buches Jesaja," VT 34 (1984): 295-320; Wim A. M. Beuken, Jesaja deel IIB (De prediking van het Oude Testament; Nijkerk: Callenbach, 1983), 277-78; idem, "Isaianic Legacy," 50-51; idem, Jesaja IIIA, 7-8, 19-39; Steck, "Beobachtungen," 229-30; idem, "Tritojesaja im Jesajabuch," 402-3; Graham I. Davies, "The Destiny of the Nations in the Book of Isaiah," in Book of Isaiah, ed. Vermeylen, 118; Dwight W. Van Winkle, "The Meaning of $y \bar{a} d$ wāse èm in Isaiah lvi 5," VT 47 (1997): 378-85, esp. 384; Sweeney, "Reconceptualization," 46; Oswalt, "Righteousness in Isaiah," 178; Berges, Das Buch Jesaja, 509-15; Gosse, "Sabbath, Identity and Universalism," 359-70.

Some scholars consider the relationship between chs. 55 and 56 compelling enough to deny the validity of the Trito-Isaianic concept; see, e.g., Fritz Maass, “'Tritojesaja'?” in Das ferne und

This article was published in JBL 127/4 (2008) 671-95, copyright $\odot 2008$ by the Society of Biblical Literature. To purchase copies of this issue or to subscribe to JBL, please contact SBL Customer Service by phone at 866-727-9955 [toll-free in North America] or 404-727-9498, by fax at 404-727-2419, or visit the online SBL Store at www.sbl-site.org. 
the relationship of 56:9-57:13 with Isa 55:1-13. ${ }^{51}$ Yet these observations of the intertextual relationship of both $56: 1-8 / 9$ and $56: 10-57: 13$ with one and the same passage (Isa 55:1-13) raise the question whether the gap between Isa $56: 1-8 / 9$ and the following text is indeed as wide as generally supposed, or are 56:1-8/9 and 56:1057:13 also related?

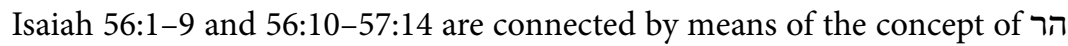
קדשי, "my holy mountain" (56:7; 57:13). ${ }^{52}$ In addition to this concept, the theme of "servants of YHWH" plays a central role throughout Trito-Isaiah. ${ }^{53}$ Both themes are relevant to the message of Trito-Isaiah: the "mountain of YнHw" is the place where עבדים עב ("servants") of YHwh, the righteous ones, will live. However, in contrast to what seems to be an impressive image, we are confronted in 56:10-59:16 with the fact that this place is destroyed by the oppression of the righteous ones. ${ }^{54}$ Although the term "servants of YHWH" is missing completely from 56:10-59:21, it is clear

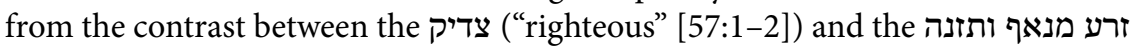
("seed of an adulterer and a whore" [57:3-4]), that the "righteous" are the true זרע מנדע ("seed") of the Servant $(53: 10 ; 54: 3) .{ }^{55}$ On the other hand, the "seed of the adulterer and the whore" is not described any further, but the "harlot" herself is described in a way that resembles the description of the daughter of Babylon (Isa 47:9-15). ${ }^{56}$ The description is rather harsh, but it appears that the author of Trito-

nahe Wort: Festschrift Leonhard Rost zur Vollendung seines 70. Lebensjahres am 30. November 1966 gewidmet (ed. Fritz Maass; BZAW 105; Berlin: Töpelmann, 1967), 153-63; Aimo E. Murtonen, "Third Isaiah-Yes or No? Review Article of Karl Pauritsch, Die neue Gemeinde: Gott sammelt Ausgestossene und Arme (Jesaia 56-66)," Abr-Nahrain 19 (1980): 20-42; Watts, Isaiah 34-66; William L. Holladay, "Was Trito-Isaiah Deutero-Isaiah after all?" in Writing and Reading the Scroll of Isaiah, ed. Broyles and Evans, 193-217; Peter Höffken, "Eine Bemerkung zu Jes 55,1-5: Zu buchinternen Bezügen des Abschnitts," ZAW 118 (2006): 239-49. In addition, see the critical remarks in Seitz, "Isaiah, Book of (Third Isaiah)," 502-4.

${ }^{51}$ Beuken, "Isaianic Legacy," 57-61, who states that both passages have the intention to comment on Isaiah 55. See also Steck, "Beobachtungen," 229-30.

52 Beuken, "Isaianic Legacy," 50.

${ }^{53}$ Beuken, "Trito-Jesaja," 78-83; idem, "Main Theme," 85 and passim; idem, "Isaiah Chapters lxv-lxvi: Trito-Isaiah and the Closure of the Book of Isaiah," in Congress Volume: Leuven 1989 (ed. John A. Emerton; VTSup 43; Leiden: Brill, 1991), 204-21; Joseph Blenkinsopp, "Who Is the Saddiq of Isaiah 57:1-2," in Studies in the Hebrew Bible, Qumran, and the Septuagint Presented to Eugene Ulrich (ed. Peter W. Flint et al.; VTSup 101; Leiden: Brill, 2006), 109-20, esp. 116-19; idem, "Servants of the Lord," 1-23; idem, "Servant and Servants," 166-70; Berges, "Armen im Buch Jesaja," 170-75.

${ }^{54}$ Beuken, "Isaianic Legacy," 56.

${ }^{55}$ Beuken, "Main Theme," 68; idem, "Isaiah lxv-lxvi," 213-15; Blenkinsopp, "Who Is the Saddiq," 116-17; Berges, "Armen im Buch Jesaja," 169-70.

${ }^{56}$ Beuken, "Isaianic Legacy," 52-56; idem, "Main Theme," 69-70; Mark E. Biddle, "Lady Zion's Alter Egos: Isaiah 47,1-15 and 57,5-13 as Structural Counterparts," in New Visions of Isaiah, ed. Melugin and Sweeney, 124-39. This application of the imagery of the "servants of YHWH" and

This article was published in JBL 127/4 (2008) 671-95, copyright @ 2008 by the Society of Biblical Literature. To purchase copies of this issue or to subscribe to JBL, please contact SBL Customer Service by phone at 866-727-9955 [toll-free in North America] or 404-727-9498, by fax at 404-727-2419, or visit the online SBL Store at www.sbl-site.org. 
Isaiah has strong reasons to criticize the group he had in mind. Who are these "godless" ones? Is it possible to draw a picture of them, similar to the image of the "servants" and the "righteous" in Trito-Isaiah? ${ }^{57}$

In his study of the book of Isaiah, Ulrich Berges argues that Isa 56:3-8 contains a criticism of the expectations formulated in chs. 60-62 (esp. the less favorable expectations regarding foreigners). ${ }^{58}$ Isaiah 60:10 states that ("foreigners") have to build Jerusalem's walls, and kings will minister (שרת) to the city, but the Israelites will be כהני יהוה ("ministers of בני הנכר our God" [61:6]). ("foreigners") will minister to YHWH (שרת) and be his servants. The fact that the animals of other people will be acceptable upon the altar (60:7) is not comforting if those who bring them are not identified. However, Isa 56:7 states that their [the בני הנכר ) offerings and sacrifices will be accepted.

Over against 60:4 they [the Servants] were convinced that Yнwh's gathering (קבץ) could not solely be restricted to the exiled Jews, but must exceed this by far (קב 56:8 a threefold (קבץ). When a better memorial within the Temple(!) is promised to the eunuchs than the physical descendants (56:5), this is once again a reference to 60:4: the sons of the exiled Jews will come to Zion and their daughters will be carried on the shoulders. ${ }^{60}$

the "servant's seed" to the righteous, and, on the other hand, "children of the adulterer" to the godless (imagery that is close to that used of the "daughter of Babylon"; Beuken, "Isaianic Legacy," esp. 55-56) confirms Marjo C. A. Korpel's analysis of the imagery of Zion in ch. 54 as the "female servant" of Yнwн ("The Female Servant of the Lord in Isaiah 54," in On Reading Prophetic Texts: Gender Specific and Related Studies in Memory of Fokkelien van Dijk-Hemmes [ed. Bob Becking and Meindert Dijkstra; Biblical Interpretation Series 18; Leiden: Brill, 1996], 153-67).

${ }^{57}$ For this picture, see the literature mentioned in n. 52 above.

${ }^{58}$ Berges, Das Buch Jesaja, 511-13. Regarding Isaiah 60-62, Johannes C. de Moor ("Structure and Redaction in Isaiah 60,1-63,6," in Studies in the Book of Isaiah, ed. van Ruiten and Vervenne, 343) argues on the basis of Isa 62:8b, "foreigners will not drink your must for which you have laboured" and 61:5-6 "foreigners shall till your land and dress your vines, but you shall be called priests of Yhwh," that there is a contradiction regarding the foreigners, which in his view is due to a process of editing. However, the contradiction is not very convincing because the work of a slave could be considered to be the work of the master; moreover, in Isa $62: 8 \mathrm{~b}$ the "foreigners" are parallel to "enemies," who are not favorable to foreigners (similar to Isa 61:5-6). Those texts may therefore be from the same author, and thus there is no need to consider a diachronic process in this text. In this sense Berges's observation that such editorial reconstructions in Isaiah 60-62 have failed can only be correct (Das Buch Jesaja, 428, with nn. 66-68).

${ }^{59}$ However, Beek ("De vreemdeling," 22) and Bultmann (Der Fremde, 212) apparently do not see a contradiction between Isaiah 60-62 and the sayings in Isa 56:1-8.

${ }^{60}$ Berges, Das Buch Jesaja, 512-13: “Gegenüber 60,4 waren sie der Ansicht, JHWH's Sammlung (קבץ) könne sich nicht ausschließlich auf die Diasporajudenschaft beziehen, sondern müsse weit darüber hinausgreifen (in 56,8 dreifaches קבץ). Wenn den Verschnittenen im Tempel(!) ein besseres Denkmal als das leiblicher Nachkommenschaft verheißen ist $(56,5)$, so ist damit ein weit-

This article was published in JBL 127/4 (2008) 671-95, copyright $\odot 2008$ by the Society of Biblical Literature. To purchase copies of this issue or to subscribe to JBL, please contact SBL Customer Service by phone at 866-727-9955 [toll-free in North America] or 404-727-9498, by fax at 404-727-2419, or visit the online SBL Store at www.sbl-site.org. 
In addition to these parallels, reference should be made to פנו דרך ("prepare the way"), an image that Isa $62: 10$ borrowed from Isa 40:3, which is taken up again in $57: 14 .{ }^{61}$ In the context of chs. 60-62 the announcement is focused on the rebuilding of the temple and Jerusalem, yet in 57:14 it is applied in a metaphorical sense related to removing the sinful situations in the community that are due to backsliding בדרד לבו, "in the way of his own heart" (57:17), ${ }^{62}$ which seems to refer back to לדרכם פנו, "they turned to their own way" (Isa 56:11; see also 53:6). ${ }^{63}$ The author of chs. 56-59 seems to apply a deliberate pun here, because in the latter verse the verb פנה is used in the qal, as an indication of turning away from the way of Y $\mathrm{HwH}$, while in Isa 57:14 (similar to Isa 40:3; 62:10) the verb פנה is used in the piel in the sense of "preparing" the way of YHWH (or the people). ${ }^{64}$ This small morphological difference indicates an important theological difference: between "turning to their own way" or "preparing the way of Yнwн," which also differs from the use of the verb in Isa 62:10.65

However, it is not just an exclusive approach of the postexilic community that is criticized in our passage. ${ }^{66}$ There were strong reservations in general regarding the postexilic community, which are presented in the main part of Trito-Isaiah. The contrast is clear from Isaiah 65-66, where the temple cult was criticized with harsh words for the community. ${ }^{67}$ Isaiah $65: 5$ a reads "[a people] who say 'Keep to yourself, do not come near me, because I am too holy for you." "68 Yet the preceding

eres Mal auf 60,4 angespielt, die Söhne der Diasporajuden würden zum Zion kommen und deren Töchter würde man auf der Schulter tragen."

${ }^{61}$ See Berges, Das Buch Jesaja, 461, with n. 232; Hans M. Barstadt, "Isa. 40,1-11: Another Reading," in Congress Volume: Basel 2001 (ed. André Lemaire; VTSup 92; Leiden: Brill, 2002), $225-40$.

${ }^{62}$ Berges, Das Buch Jesaja, 461.

${ }^{63}$ Beuken refers to the parallel between Isa 53:6 and 56:11 ("Isaianic Legacy," 60).

${ }^{64}$ See HALAT, 885; Wilhelm Gesenius' Hebräisches und Aramäisches Handwörterbuch über das Alte Testament (ed. Frants Buhl; 17th ed.; Leipzig: Vogel, 1921), 645-46; BDB, 815; Klaus Koch, "דֶרִּ" TWAT 2:293-312, esp. 309; Josef Schreiner, “פנה", TWAT 6:617-25, esp. 621.

${ }^{65}$ That the author of Isaiah 56-57 (at least, but maybe chs. 56-59) deliberately uses themes from chs. 60-62, may also be clear from the use of the "watchman" metaphor of Isa 62:6, which received a different, critical meaning in 56:10. There it is said that the watchmen have become "blind ... they are all dumb dogs, they cannot bark; dreaming, lying down, loving to slumber," in contrast to the watchmen of 62:6. The latter image clearly belongs to the Tritoisaianic Grundbestand; see Berges, Das Buch Jesaja, 455, with n. 193.

${ }^{66}$ Taking Isa 56:1-8 as a polemic with Deut 23:2-9; Ezekiel 44; Ezra 9; Nehemiah 9; see Westermann, Isaiah 40-66, 249-50; Watts, Isaiah 34-66, 249; Berges, Das Buch Jesaja, 510-12; etc.

${ }^{67}$ Berges, "Who Were the Servants?" 5.

${ }^{68}$ For the translation of the verb with suffix קדשתיך, in which the suffix is understood to be the equivalent of the preposition $ל$ with a suffix, see John A. Emerton, "Notes on the Text and Translation of Isaiah xxii 8-11 and lxv 5," VT 30 (1980): 437-51, esp. 446-51.

This article was published in JBL 127/4 (2008) 671-95, copyright @ 2008 by the Society of Biblical Literature. To purchase copies of this issue or to subscribe to JBL, please contact SBL Customer Service by phone at 866-727-9955 [toll-free in North America] or 404-727-9498, by fax at 404-727-2419, or visit the online SBL Store at www.sbl-site.org. 
depiction of this group suggests an ethical behavior that is far from holy, righteous, and according to the Torah (65:3-4). In 66:3 a clear juxtaposition of legitimate cultic behavior and sinful conduct is found, describing the behavior of those bringing legitimate offerings but simultaneously באשר לא־חפצתי בחרו, "choosing what does not please me" (66:4; 65:12), which might be contrasted with the formulation in 56:4, בחרו באשר חפצתי, "who choose the things that please me."69

\section{The Direct Context: Isaiah 56:10-59:21}

Isaiah 56:10-57:13. A picture similar to that drawn above emerges from the direct context of our passage. The first verses say that the shepherds (i.e., leaders) "turned their own way to their own gain" (56:11). In other words, in order to look for their own profit, they forsake those who are entrusted to them, and so the righteous, the devout, those who walk in peace perish (57:1-2). ${ }^{70}$ After the description of how the righteous perish, the polemic picks up again with ואתם, "but you" (57:3), in a strong antithesis to those who are guilty of this oppression. ${ }^{71}$ It is remarkable, therefore, that the accusation does not immediately focus on socio-economic abuses, but refers rather to religious abuses by those who pervert and pollute the mountain of YHWH, making it the opposite of what YHWH really intended for the mountain. ${ }^{72}$ The group addressed here is polemically depicted as the seed of a whore, resembling the description of the daughter of Babylon in Isa 47:9-15. They are accused of syncretistic behavior, of being unfaithful to YHWH. The colorful description resembles that of Anat searching for her love $\mathrm{Ba} \mathrm{a}^{\mathrm{C}} \mathrm{al}$, in the story of $\mathrm{Ba}^{\mathrm{C}} \mathrm{al}$

${ }^{69}$ Berges, Das Buch Jesaja, 522.

${ }^{70}$ Ibid., 422.

${ }^{71}$ See Steck ("Beobachtungen," 230-31), who states that the criticism is directed at the leaders (Isa 56:10-12). According to Berges (Das Buch Jesaja, 422), Isa 57:6-13a, employing the feminine "you," is directed against all the residents of "daughter Zion." With regard to the following chapter (Isaiah 58), this is not unlikely. If so, this would imply that the prophet creates a strong antithesis between the "servants" and "righteous ones," on the one hand, and, on the other hand, the group that seems to consist of the whole house of Jacob (Isa 58:1), which is vulnerable to criticism. However, even then one must ask whether in this case, too, the criticism is leveled especially against the leaders in Jerusalem, who are not able to move the people in the right direction (Isa 56:10-12).

${ }^{72}$ Beuken, "Isaianic Legacy," 52-56. Concerning Isa 56:9-57:13 Beuken (Jesaja IIIA, 75) writes: "This passage is related to the prologue (56:1-8) as a description of what really takes place on the holy mountain over against the program YHWH developed for his mountain" ("Deze passage verhoudt zich tot de proloog [56:1-8] als een beschrijving van wat zich in werkelijkheid afspeelt op de heilige berg, tot het programma dat YHWH voor zijn berg heeft ontworpen").

This article was published in JBL 127/4 (2008) 671-95, copyright $\odot 2008$ by the Society of Biblical Literature. To purchase copies of this issue or to subscribe to JBL, please contact SBL Customer Service by phone at 866-727-9955 [toll-free in North America] or 404-727-9498, by fax at 404-727-2419, or visit the online SBL Store at www.sbl-site.org. 
and Mot (KTU 1.6). ${ }^{73}$ The prophetic text is not to be taken as an accurate depiction of the syncretistic developments during the postexilic era, but rather as a general description of the religious situation-if these polemics offer a reliable picture of the opposed group. ${ }^{74}$

Yet there is a small detail in the description that also emphasizes the contrast between the צדיק ("righteous") and the adulteress. In 57:8 it is stated, "you set up behind the door and the doorpost your symbol (זכרנך)." In view of the terminology in the accusation, this might refer to a kind of a phallic symbol. ${ }^{75}$ The word אות can be viewed as parallel to "sign") in 55:13. ${ }^{76}$ Interestingly, the latter verse is parallel to 56:5, where יד ("hand") is used in the sense of memorial stone. However, 57:8 also uses the word יד יד, but now also as a possible euphemism for "phallus." 77 It seems that the choice of these words is not coincidental but deliberate in the context of the contrast between those who hold faithfully to the covenant of YHWH and those who are said to act unfaithfully, seeking after other lovers. ${ }^{78}$ Those who hold to the covenant of YHWH will receive a יד ("memorial") within the temple that is worth more than children. These details emphasize the relationship of the first part of Trito-Isaiah (56:1-9) with its direct context (56:1059:16).

Isaiah 58:1-59:8. This passage emphasizes the contrast found in the first chapters of Trito-Isaiah. The group with whom the author is engaged in a controversy is depicted as apparently behaving righteously, observing the Sabbath and the fast but at the same time ignoring the needs of the poor and the oppressed (58:1-59:8). In contrast, there is a group of people (foreigners and eunuchs) who are not allowed to enter the community because of the Torah but who act faithfully according to what pleases YHWH (56:4). In this section (58:1-14) the Sabbath, too, is a matter of critique (58:13). The Sabbath, together with fasting, should be reconsidered in the

\footnotetext{
${ }^{73}$ See Beuken (Jesaja IIIA, 64-65, 69), who draws the parallel with the Ugaritic myth. For translations, see Johannes C. de Moor, An Anthology of Religious Texts from Ugarit (Nisaba 16; Leiden: Brill, 1987), 82-99; Mark S. Smith, “The Baal Cycle," in Ugaritic Narrative Poetry (ed. S. B. Parker; SBLWAW 9; Atlanta: Scholars Press, 1997), 83-180, esp. 151-64; Nicolas Wyatt, Religious Texts from Ugarit: The Words of Ilimilku and His Colleagues (Biblical Seminar 53; Sheffield: Sheffield Academic Press, 1998), 128-45.

${ }^{74}$ Beuken, Jesaja IIIA, 61.

${ }^{75}$ HALAT, 260; see also Ronald E. Clements, "זכר," TWAT 2:593-99, esp. 594; Beuken, Jesaja IIIA, 66; Koole, Jesaja III, 95-97; BDB, 272 ("memorial"); Gesenius, Handwörterbuch, 18th ed., 302 (“a pagan symbol"); DCH 3:112 ("symbol”).

${ }^{76}$ Cf. Exod 13:9; Josh 4:6. See DCH 3:112; Koole, Jesaja III, 96.

${ }^{77}$ HALAT, 370; Gesenius, Handwörterbuch, 18th ed., 438; DCH 4:94; Peter Ackroyd, "דיד," TWAT 3:421-55, esp. 430; Beuken, Jesaja IIIA, 65, 68; Koole, Jesaja III, 99-100.

${ }^{78}$ Berges, Das Buch Jesaja, 469.
}

This article was published in JBL 127/4 (2008) 671-95, copyright $\odot 2008$ by the Society of Biblical Literature. To purchase copies of this issue or to subscribe to JBL, please contact SBL Customer Service by phone at 866-727-9955 [toll-free in North America] or 404-727-9498, by fax at 404-727-2419, or visit the online SBL Store at www.sbl-site.org. 
light of what is just and righteous. ${ }^{79}$ The wording suggests that the mainstream postexilic community-or at least those who play an important role in this community-demonstrated behavior that was only seemingly in line with the Torah (keeping Sabbath, fasting, making offerings) but in fact ignored one of the most fundamental aspects of the Torah, care for the oppressed, the poor, and the hungry $(58: 6-7,9 \mathrm{~b}-10)$.

Isaiah 59:15-21. The final verses of ch. 59 are devoted to the ("righteousness") and ישועה ("salvation") that are at hand (twice in 59:16b-17a). YHwH is coming because he saw that "there was no justice (משפט)... and he was appalled because there was no one to intervene" (59:15-16). This description recalls that of the Servant in ch. 53, but here the prophecy is related to his ("seed"), the righteous one of 57:1-2. ${ }^{80}$ The wording of this passage (59:15-20) resembles the first verses of Trito-Isaiah (56:1-2) and in that sense these two passages form the opening and closing of these critical chapters (56-59). The section opens with an exhortation to do צמשקה ("ighteousness") because God's צדקה ("justice") and ישוע ("salvation") are at hand. The polemic closes with the announcement that because YHwh saw no משפט in the squares, God's ישוע are at hand, coming to Zion as a redeemer (גאל) to those who turn from transgression (59:15a, 20). ${ }^{81}$ In fact, the opening and closing cannot be understood without each other: the opening is easily misunderstood if read apart from the following chapters, ${ }^{82}$ and

${ }^{79}$ This assessment is in line with the critique of the cult found already in Proto-Isaiah (e.g., 1:11, 13-14); see Koole, Jesaja III, 19. Gosse describes the approach in 56:1-2 as a contrast to 1:11, 13-14 ("Sabbath, Identity and Universalism," 359-60). Yet the clear criticisms in Trito-Isaiah of behavior that appears to be cultically correct going hand in hand with injustice make the supposed contrast questionable. Berges doubts whether 58:13-14 originally belongs to this literary context because, in his view, the ethical component is missing (Das Buch Jesaja, 475-76), but the critical reference to דרכיך ("your own ways") and ("your own business") in 58:13b seems to be strong enough to warrant its present position; see briefly Beuken, Jesaja IIIA, 99, 116.

${ }^{80}$ Beuken, Jesaja deel IIB, 270-72; idem, “Trito-Jesaja," 79; idem, "Main Theme," 67-68; Blenkinsopp, "Servants of the Lord," 16-17; idem, "Servant and the Servants," 166-73; idem, "Who Is the Saddiq," 116-17, 119-20; Berges, "Armen im Buch Jesaja," 170.

81 The coming of YнWH to those "who turn from transgression" (59:20) is an act of salvation, because those "who depart from evil" are those who suffer (59:15a); note that the verbs and שוב are often used side by side (1 Sam 7:3; 2 Chr 30:9; Isa 1:25; Jer 4:1; 32:40; Mal 3:7). The general division in this verse (between $15 \mathrm{a}$ and $15 \mathrm{~b}$ ) seems to prevent commentators from seeing the relationship between v. 15a and v. 20 (despite many other points of contact with the preceding passage); see, e.g., Beuken, Jesaja IIIA, 148-49; Koole, Jesaja III, 216; Berges, Das Buch Jesaja, 477-79.

${ }^{82} \mathrm{Cf}$. the criticisms above of those interpretations that consider ch. 56 only as a promise of God's salvation, without taking into account the strong emphasis that is present in the first chapter of Trito-Isaiah on the right ethical behavior. This force is even more clear in the following

This article was published in JBL 127/4 (2008) 671-95, copyright ( 2008 by the Society of Biblical Literature. To purchase copies of this issue or to subscribe to JBL, please contact SBL Customer Service by phone at 866-727-9955 [toll-free in North America] or 404-727-9498, by fax at 404-727-2419, or visit the online SBL Store at www.sbl-site.org. 
without the opening it is not clear who is the subject of the announced salvation and righteousness. Understanding 56:1-9 as the opening of the first four chapters of Trito-Isaiah enables us to read this section as the prelude to the critical passages in the remaining chapters $(56: 10-59: 20) .{ }^{83}$

The general wording of the criticisms in these four chapters makes it difficult to determine precisely which group in the postexilic community is being targeted here. It seems clear, however, that there are several religious and social divisions in the community. ${ }^{84}$ The first chapters of Trito-Isaiah seem to reflect the perspective of a group that characterizes itself as צדיק ("righteous") and עבדים ("servants") of Yнwн. Yet it is not certain whether the harsh criticisms in these chapters actually reflect the views of this group or are the rhetorical language of a "preacher." 85 There is also a group that is accused of syncretism, of committing adultery (metaphorically), following its own ways $(56: 11 ; 57: 10)$ and only ostensibly obeying the Torah concerning Sabbath and fasting. They are called the רעים ("shepherds"); they are the leaders; they influence the lawsuit; they are wealthy (since they are not hungry $[58: 7,10])$ with an eye to their own profit. This suggests that at the socioeconomic level the latter group belongs to the upper class of Jerusalem, which collaborated with the Persian empire. ${ }^{86}$ Apparently they try to keep some people out of the com-

chapters (57-59). In my view, this is one of the main weaknesses of commentaries that ignore this macro-structural element of Trito-Isaiah. See esp. the delimitations of units in Watts, Isaiah 34-66, 219-305, and, regarding 59:15b-21, esp. 284-88; see also Koole, Jesaja III, 25-27.

${ }^{83}$ Beuken considers Isa 56:1-8 to be the prologue to Trito-Isaiah (Jesaja IIIA, 14-15, 19).

${ }^{84}$ Rainer Albertz, Religionsgeschichte Israels in alttestamentlicher Zeit (GAT 8/2; Göttingen: Vandenhoeck \& Ruprecht, 1992), 538-41; idem, "Religion in Israel during and after the Exile," in The Biblical World (ed. John Barton; 2 vols.; London: Routledge, 2002), 2:101-24, 114-15; John Kessler, "Persias Loyal Yahwists: Power Identity and Ethnicity in Achaemenid Yehud," in Judah and the Judeans in the Persian Period (ed. Oded Lipschits and Manfred Oeming; Winona Lake, IN: Eisenbrauns, 2006), 91-121; Lisbeth S. Fried, "The ' $a m$ ha'ares in Ezra 4:4 and Persian Imperial Administration," in Judah and the Judeans in the Persian Period, 123-45; Lester L. Grabbe, "Israel under Persia and Greece," in The Biblical World, ed. Barton, 1:440-57, esp. 441-45.

${ }^{85}$ See Lester L. Grabbe, A History of the Jews and Judaism in the Second Temple Period, vol. 1, Yehud: A History of the Persian Province of Judah (Library of Second Temple Studies 47; London: T\&T Clark, 2004), 256-61, esp. 260.

${ }^{86}$ Large numbers of people in Yehud became impoverished during the Persian period. There is a wealth of literature on the socioeconomic and political situation of Yehud during that era; see, e.g., Adam S. van der Woude, "Geschiedenis van het volk Israël en zijn godsdienst tot de tijd van Alexander de Grote: Een proeve. B: Vanaf de tijd van de babylonische ballingschap tot de komst van Alexander de Grote," in Bijbels Handboek 2a: Het Oude Testament (ed. Adam S. van der Woude; Kampen: Kok, 1982), 141-71, esp. 153, 158, 162; Eric M. Meyers, "The Persian Period and the Judean Restoration: From Zerubbabel to Nehemiah," in Ancient Israelite Religion: Essays in Honor of Frank Moore Cross (ed. Patrick D. Miller, Jr., et al.; Philadelphia: Fortress, 1987), 50921; Gösta W. Ahlström, The History of Palestine from the Palaeolithic Period to Alexander's Conquest

This article was published in JBL 127/4 (2008) 671-95, copyright (־ 2008 by the Society of Biblical Literature. To purchase copies of this issue or to subscribe to JBL, please contact SBL Customer Service by phone at 866-727-9955 [toll-free in North America] or 404-727-9498, by fax at 404-727-2419, or visit the online SBL Store at www.sbl-site.org. 
munity (or out of certain positions) on the basis of dubious religious arguments, for example, it is "too holy for you" (65:5) ${ }^{87}$ Further, passages stating that there are obstructions in the way of God's people $(57: 14)^{88}$ and a yoke on the neck of the people $(58: 6,9)^{89}$ seem to imply an abuse of power. More important, however, the criticism suggests that the attitude of the leading class is characterized by haughtiness and ignorance. In this sense Isa 56:1-9 criticizes the upper class of Jerusalem implicitly, by allowing entrance to those who have been excluded by the "shepherds" of the people (56:11). Isaiah 56:3-9 offers true comfort for the oppressed and the foreigners, those who have been barred from the community. At the same time, this text ventures a strong criticism of those who want to exclude foreigners and the oppressed from the community, emphasizing as it does the ethical aspects over the formal aspects of membership. ${ }^{90}$

(JSOTSup 146; Sheffield: JSOT Press, 1992), 812-906, esp. 850-52, 866; Albertz, Religionsgeschichte Israels, 538-41; Mary J. W. Leith, "Israel among the Nations: The Persian Period," in The Oxford History of the Biblical World (ed. Michael J. Coogan; New York: Oxford University Press, 1998), 367-419, esp. 400-402; Pierre Briant, "Histoire impériale et histoire régionale: À propos de l'histoire de Juda dans l'Empire achéménide," in Congres Volume: Oslo 1998 (ed. André Lemaire and Magne Sæbø; VTSup 80; Leiden: Brill, 2000), 235-46; Herbert Donner, Geschichte des Volkes Israel und seiner Nachbarn in Grundzügen (GAT 4; 3rd ed.; Göttingen: Vandenhoeck \& Ruprecht, 2001), 423-73, esp. 449-53; Erhard S. Gerstenberger, Israel in der Perserzeit: 5. und 4. Jahrhundert v. Chr. (Biblische Enzyklopädie 8; Stuttgart: Kohlhammer, 2005), esp. 51-54; see also the articles in Judah and the Judeans in the Persian Period.

${ }^{87}$ See Watts, Isaiah 34-66, 343, referring to the application of the same terminology in Ezek 44:5, 13, 15; Koole, Jesaja III, 389, who states that "self-conceit has become blasphemous" ("de eigendunk is blasfemie geworden"). It is dubious whether these words have to be understood in the sense of the aforementioned syncretistic cults (65:3-4; see Wim A. M. Beuken, Jesaja deel IIIB [De prediking van het Oude Testament; Nijkerk: Callenbach, 1989], 67), and has most likely to be considered in relation to the ostensible holiness, which we also find in the contrasts of 66:3 and which will turn against them (ibid.); in addition, see the quotation from T. Mos. 7:10 below in section V. Isaiah 65:5a is translated "Keep to yourself, do not come near me, for I am too holy for you."

${ }^{88}$ Beuken, Jesaja IIIA, 82-83; Berges, Das Buch Jesaja, 470. It is doubful whether Isa 57:14 should be understood in a spiritual sense, taking the obstructions in the sense of guilt, or feeling guilty, as Koole suggests (Jesaja III, 119-20).

${ }^{89}$ Regarding the "yoke," it is not clear what is meant, yet in the context of the first verse (58:6) it may be related to debt slavery and, in a more general sense, to every form of illegitimate deprivation of liberty. See Beuken, Jesaja IIIA, 107-8; Koole, Jesaja III, 155. The second verse (58:9) could be a reference to the first, especially in relation to false lawsuits, which are mentioned several times and are used to strengthen the position of the upper class (Beuken, Jesaja IIIA, 111).

${ }^{90}$ The text of Isa 56:1-8(9) thus does suggest that it was a real issue during the Persian era (if such a dating of this passage is correct) and that who was a Jew and how one might become one were important questions; pace Grabbe, History of the Jews and Judaism, 165. Intriguing is Bob Becking, "Law as Expression of Religion (Ezra 7-10)," in Yahwism after the Exile: Perspec-

This article was published in JBL 127/4 (2008) 671-95, copyright ( 2008 by the Society of Biblical Literature. To purchase copies of this issue or to subscribe to JBL, please contact SBL Customer Service by phone at 866-727-9955 [toll-free in North America] or 404-727-9498, by fax at 404-727-2419, or visit the online SBL Store at www.sbl-site.org. 


\section{Comfort and Criticism in Some Early Interpretations}

In general, the text of Isa 56:1-8(9) is transmitted in the versions in a fashion that is quite close to the MT, and this applies to the rendering in Targum Jonathan as well. It appears that the targumist did not have any problems with the fact that the son of the stranger or the eunuch was included in God's people. In 56:8, however, it is remarkable that those who will be gathered are the exiled, shifting the focus of the text from "strangers" 91 and "eunuchs" to the exiled people, who will be gathered. ${ }^{92}$ In Targum Jonathan, v. 9 is taken as a continuation of v. 8, as might be understood from the break after v. $9,{ }^{93}$ yet the verse is expanded considerably by a clause that states that the kings who were gathered to distress Jerusalem will become food for the beasts of the field and forest. This seems to be an adaptation of the text in line with the thoughts found in Ezek 39:17-29, to which reference has already been made. In this sense the targumist emphasizes the way of reasoning indicated in the accentuation and delimitation of the MT: the righteous shall prosper, while the wicked shall suffer. ${ }^{94}$

It was noted above that the positive elements in Isa 56:1-8(9) sometimes overshadow the critical and ethical aspects of the text in the Christian tradition. In Jewish tradition also the pericope had its impact and was quoted in the discussion of converts because of its positive attitude toward them. Next to texts from the Torah that reflect an open attitude toward converts, reference is made especially to Isa 56:6-7, as in the discussion of Passover in Mekhilta deRabbi Ishmael. It is stated that Yнwh loves converts, referring to Exod 23:9; 22:20; and Deut 10:19, but also "because the Bible often applies the same terms to them as to Israelites: Israelites and converts are called servants, ministers and friends. Also a covenant is connected to both the converts and Israel, acceptance is used with regard to both

tives on Israelite Religion in the Persian Era (ed. Rainer Albertz and Bob Becking; Studies in Theology and Religion 5; Assen: Van Gorcum, 2003), 18-31. He describes the possibly more formal development within the Jewish community in a positive way against its historical background in opposition to the negative descriptions by earlier OT scholars of the deeds and doings of Ezra and Nehemiah as Gesetzesreligion, e.g., Gerhard von Rad and Theodoor C. Vriezen. The passage under discussion (Isa 56:1-8[9]) suggests that not everyone in Judean society approved of this formal approach.

${ }^{91}$ Or "sons of the gentiles/peoples" (בני עממיא) as Targum Jonathan renders the Hebrew בני הנכר For this and other changes in the text, see de Hoop, "Isaiah 56:1-9 in Targum Jonathan."

${ }^{92}$ See Bruce D. Chilton, The Isaiah Targum: Introduction, Translation, Apparatus and Notes (ArBib 11; Wilmington, DE: M. Glazier, 1987), 109 (notes).

${ }^{93}$ See n. 21 above.

${ }^{94}$ Freedman and Cohen, "Masoretes as Exegetes," 37.

This article was published in JBL 127/4 (2008) 671-95, copyright @ 2008 by the Society of Biblical Literature. To purchase copies of this issue or to subscribe to JBL, please contact SBL Customer Service by phone at 866-727-9955 [toll-free in North America] or 404-727-9498, by fax at 404-727-2419, or visit the online SBL Store at www.sbl-site.org. 
groups." 95 Converts are even more precious to Yнwн than the Israelites themselves, argued Simeon b. Yohai, "for those whom the king loves are greater than those who love the king." 96

We referred to the example of the story of the conversion of the eunuch from Ethiopia (Acts 8:26-40), of which Johannes Schneider wrote:

In Ac. 8:27ff. we read of the eunuch of Queen Candace who comes to faith and is baptised. Here the prophetic saying in Is. 56:3, 4 finds its true and complete fulfillment. The eunuch is no longer shut out from the kingdom of God and the Christian community. ${ }^{97}$

Though it is doubted by scholars that Luke intends to refer to the Isaian passage or to the law concerning eunuchs (Deut 23:1), ${ }^{98}$ the word घu่voũ $\chi 05$ ("eunuch") seems to be applied deliberately here, since it was used five times in this pericope. ${ }^{99}$ Nevertheless, even if the focus of Isa 56:1-9 is different from the general interpretation of this passage (based on Acts 8), I think that the author deliberately uses the term $\varepsilon \dot{\nu} \nu \tilde{u} \chi 0 \varsigma$ to refer to Isa 56:1-9. ${ }^{100}$ Though this might be a

${ }^{95}$ Gary G. Porton, The Stranger within Your Gates: Converts and Conversion in Rabbinic Literature (CSHJ; Chicago: University of Chicago Press, 1994), 58 (with 286 nn. 77, 78, 80, 81, which refer to Isa 56:6, 4, and 7 as the sole texts that support this opinion). See also Beek, "De vreemdeling," 18.

${ }^{96}$ Porten, Stranger within Your Gates, 58. In this context the parable "the deer, which entered the herd of sheep of the king" from Num. Rab. 8 (148c) is a fitting example of the general attitude toward converts (the parable is quoted, e.g., in StrB 1:355-56). On the sometimes ambivalent attitude toward converts, see Emil Schürer, The History of the Jewish People in the Age of Jesus Christ (rev. and ed. Geza Vermes et al.; Edinburgh: T\&T Clark, 1987), 3.1:150-76; Menahem Stern, "Aspects of Jewish Society: The Priesthood and Other Classes," in The Jewish People in the First Century: Historical Geography, Political History, Social, Cultural and Religious Life and Institutions, vol. 2 (ed. Shmuel Safrai and Menahem Stern; CRINT I/2; Assen: Van Gorcum; Philadelphia: Fortress, 1987), 561-630, esp. 622-24.

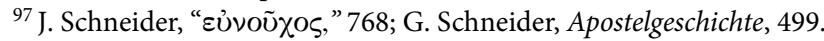

${ }^{98}$ Coert H. Lindijer, Handelingen van de Apostelen, vol. 1 (De prediking van het Nieuwe Testament; Nijkerk: Callenbach, 1975), 217.

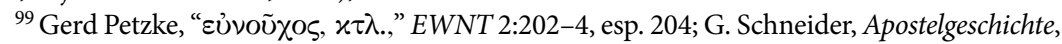
498, n. 6. Contrast, however, Pesch, Die Apostelgeschichte, 289.

${ }^{100}$ The fact that in Acts 8:32-33 Luke quotes from Isa 53:7-8 LXX suggests that Luke was

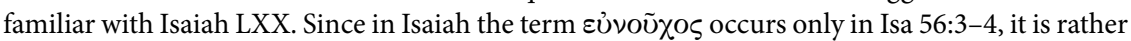
likely that Luke was familiar with this text. Pesch (Die Apostelgeschichte, 289) suggests that

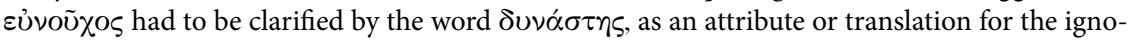
rant reader, similar to "queen of the Ethiopians" as explanation for the title "Candace." Yet this seems unlikely, since the meaning of the Greek word denotes "castrate" (see Walter Bauer, Griechisch-deutsches Wörterbuch zu den Schriften des Neuen Testaments und der übrigen urchristlichen Literatur [5th ed.; Berlin: de Gruyter, 1971], 40), and the author could have chosen to use

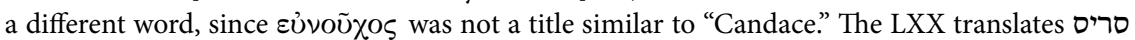

This article was published in JBL 127/4 (2008) 671-95, copyright $\odot 2008$ by the Society of Biblical Literature. To purchase copies of this issue or to subscribe to JBL, please contact SBL Customer Service by phone at 866-727-9955 [toll-free in North America] or 404-727-9498, by fax at 404-727-2419, or visit the online SBL Store at www.sbl-site.org. 
different interpretation from what was probably intended, the promissory element of Isa 56:1-9 was considered in this way to be a promise of the spread of YHwh's righteousness for all nations and all kinds of people, which already can be found in Ben Sira: "Give thanks to him who gathers (למק[בץ]) the dispersed of Israel, for his mercy endures forever" (Sir. 51:12-13). ${ }^{101}$

The critical purpose of the text did not go unnoticed either, because the text concerning eunuchs also played its role in the contrast of the godless and the righteous. Similar to the barren woman, the eunuch will receive a share in the temple of great delight (Wis 3:14; see also $4: 1$ ): ${ }^{102}$

Blessed also is the eunuch whose hands have done no lawless deed, and who has not devised wicked things against the Lord; for special favor will be shown him for his faithfulness, and a place of great delight in the temple of the Lord.

In this way the eunuch is set as an example for those who have an ordinary life, who do not encounter troubles but who do not take the law too seriously. Together with the barren woman, eunuchs are set as examples for those in the cultic community who view the "righteous" life as the basis for the exclusion of others.

However, a final example of the Wirkungsgeschichte of this passage from TritoIsaiah is the quotation of Isa $56: 7$ in the narrative of the cleansing of the temple (Matt 21:13; Mark 11:17; Luke 19:46): "My house shall be called a house of prayer for all peoples." ${ }^{03}$ Jesus is portrayed here as a prophet who revolts against the economic power of the temple aristocracy. ${ }^{104}$ During Jesus' era the priestly Sadducean

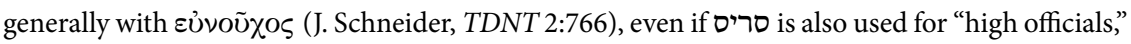
who were not necessarily castrated (see HALAT, 727; DNWSI, 804; cf., however, Benjamin Kedar-Kopfstein, "סריס," TWAT 5:948-54, regarding the Akkadian etymology of סריס, demonstrating that it was specifically used for people who were castrated). This does not imply, however, that the LXX translator and the author of Acts knew about the possible etymological background of Hebrew סריס.

${ }^{101}$ Beuken, Jesaja IIIA, 39. The Hebrew text has preserved only $p$ as first letter of the root קבץ; the other characters cannot be clearly read. For the Hebrew text, see Pancratius C. Beentjes, The Book of Ben Sira in Hebrew: A Text Edition of all Extant Hebrew Manuscripts \& a Synopsis of All Parallel Hebrew Ben Sira Texts (VTSup 68; Leiden: Brill, 1997), 92. Francesco Vattioni reads the word למקבץ without differentiating between identifiable and unidentifiable characters in the text (Ecclesiastico: Testo ebraico con apparato critico e versioni greca, latina e siriaca [Naples: Istituto Orientale di Napoli, 1968], 279).

${ }^{102}$ Beuken, Jesaja IIIA, 29; but cf. esp. Pancratius C. Beentjes, "Wisdom of Solomon 3,1-4,19 and the Book of Isaiah," in Studies in the Book of Isaiah, ed. van Ruiten and Vervenne, 413-20.

${ }^{103}$ In the version of Matthew and Luke the final words "for all peoples" are missing.

${ }^{104}$ On the meaning of Jesus' act, see the discussions in E. P. Sanders, Jesus and Judaism (London: SCM, 1985), 61-76; Ulrich Luz, Das Evangelium nach Matthäus, vol. 3, Matthäus 18-25 (EKK 1/3; Zurich: Benziger; Neukirchen-Vluyn: Neukirchener Verlag, 1997), 186-87.

This article was published in JBL 127/4 (2008) 671-95, copyright @ 2008 by the Society of Biblical Literature. To purchase copies of this issue or to subscribe to JBL, please contact SBL Customer Service by phone at 866-727-9955 [toll-free in North America] or 404-727-9498, by fax at 404-727-2419, or visit the online SBL Store at www.sbl-site.org. 
groups are depicted by their rivals as those who profited from their position in the temple. Ulrich Luz, for example, refers to a similar picture in T. Mos. 7:6-10, which might illustrate the rivals' view of the Sadducees during this period. ${ }^{105}$ The text from the Testament of Moses seems to reflect the Wirkungsgeschichte of a critical aspect of Trito-Isaiah, since it almost has the character of an anthology:

(6) But really they consume the goods of the (poor), saying their acts are according to justice, ${ }^{106}$ (7) (while in fact they are simply) exterminators, deceitfully seeking to conceal themselves so that they will not be known as completely godless because of their criminal deeds (committed) all the day long, ${ }^{107}$ (8) saying, "We shall have feasts, even luxurious winings and dinings. Indeed, we shall behave ourselves as princes." 108 (9) They, with hand and mind, will touch impure things, ${ }^{109}$ yet their mouths will speak enormous things, and they will even say, (10) "Do not touch me, lest you pollute me in the position I occupy ..." ${ }^{110}$ (T. Mos. $7: 6-10)^{111}$

It is remarkable that the story describes Jesus as quoting the words of the first pericope of Trito-Isaiah in an era and a context that seem to have close resemblances to the era of Trito-Isaiah itself. ${ }^{112}$ In this sense it seems to support my theory that the wording of Isa 56:1-9 also had a critical purport, similar to its sequence Isa 56:10-59:20.

\section{Conclusions}

It has been argued that vv. 8 and 9 of Isaiah 56 should not be separated but should be taken together as a passage that forms a bridge between the exhortation

${ }^{105}$ Luz, Matthäus 18-25, 187 n. 76; see also Sanders, Jesus and Judaism, 65-66.

${ }^{106}$ Cf. Isa 58:3-4.

${ }^{107} \mathrm{Cf}$. Isa 59:1-15

${ }^{108}$ Cf. Isa 56:10-12.

${ }^{109}$ Cf. Isa 65:3b-4; Mal 3:3

${ }^{110}$ Cf. Isa 65:5, "Keep to yourself, do not come near me, for I am too holy for you."

111 Translation after OTP, 1:930.

${ }^{112}$ For our purpose it is unimportant whether Jesus' action should be considered to be symbolic (Sanders, Jesus and Judaism, 70-71) or as a criticism (as favored by Luz, Matthäus 18-25, 186-87), since in both cases my reading of Isa 56:1-9 fits with the interpretation of Jesus' act. However, the suggestion to combine both interpretations (see Sanders, 368 n. 60 for bibliography; also mentioned by Luz, 187) seems the strongest position in this regard. Nor is it important to determine whether the quotation of Isa $56: 7$ is "original" or a later expansion of the tradition; for these matters, see, among others, Hans Dieter Betz, "Jesus and the Purity of the Temple (Mark 11:15-18): A Comparative Religion Approach," JBL 116 (1997): 455-72; Henk Jan de Jonge, "The Cleansing of the Temple in Mark 11:15 and Zechariah 14:21," in The Book of Zechariah and Its Influence (ed. Christopher M. Tuckett; Aldershot: Ashgate, 2003), 87-100.

This article was published in JBL 127/4 (2008) 671-95, copyright @ 2008 by the Society of Biblical Literature. To purchase copies of this issue or to subscribe to JBL, please contact SBL Customer Service by phone at 866-727-9955 [toll-free in North America] or 404-727-9498, by fax at 404-727-2419, or visit the online SBL Store at www.sbl-site.org. 
for justice and righteousness (56:1-2), emphasizing the importance of doing justice and keeping the Sabbath (56:3-7), and the rebuke of the leaders (56:10-12). Isaiah 56:1-9 has implicitly a critical purport for the members of the postexilic community, which is in accordance with the other critical passages in Trito-Isaiah in general (esp. chs. 65-66) as well as those in its direct context (56:10-59:21). This critical aspect recurs in the Wirkungsgeschichte of the text as is shown in Wis 3:14; T. Mos. 7:6-10; and the NT (Mark 11:17 parr.), but more positive and promissory aspects of this passage are found in rabbinic literature and in the NT (e.g., Acts 8:26-40). In general, however, it must be concluded that Isa 56:1-9 should not be read solely as a comfort for those possibly excluded from the community but should especially be considered an implicit criticism of the leaders of the community, who, in the view of the author/editor of the passage, hypocritically emphasized only those elements in the Torah that suited themselves.

This article was published in JBL 127/4 (2008) 671-95, copyright @ 2008 by the Society of Biblical Literature. To purchase copies of this issue or to subscribe to JBL, please contact SBL Customer Service by phone at 866-727-9955 [toll-free in North America] or 404-727-9498, by fax at 404-727-2419, or visit the online SBL Store at www.sbl-site.org. 